\title{
Projecting population, numbers of households and dwelling units in South Africa 201 I-202I
}

\author{
Eric O. Udjo \\ Demographic Research Division, Bureau of Market Research \\ University of South Africa, Pretoria. \\ Email: udjoe@unisa.ac.za; bororue@yahoo.com \\ Tel: +27 12429 3326; Fax: +27 124296225
}

\begin{abstract}
Future trends in population, number of households and dwelling units are critical components in strategic planning for future service delivery in South Africa. To aid planning therefore, this study analysed provincial trends in fertility, mortality and net migration as well as trends in the number of households and dwelling units. On the basis of the trends and assumptions about the future, households and dwelling units were projected for the period 20I I-202I using component functional models and ratio method. The results suggest that the size of the population aged I5 years and over in South Africa may increase from 36.4 million in mid-20II to 42.5 million in mid-202I. Gauteng province is projected to have the largest number of persons in this age group. The number of households nationally is projected to increase from 15 million in mid-20I I to 20 million by mid2021 with Gauteng having the highest number of households.
\end{abstract}

Keywords: Projections, households, dwelling units, municipalities, South Africa

\section{Résumé}

Les tendances futures dans la population, nombre de ménages et unités résidentielles est des composantes essentielles dans la planification stratégique pour la prestation des services futurs en Afrique du Sud. Pour faciliter la planification par conséquent, cette étude a analysé tendances provinciales en fécondité, mortalité et migration nette ainsi que les tendances du nombre de ménages et de logements. Compte tenu des tendances et des hypothèses quant à l'avenir, ménages et unités résidentielles ont été prévues pour la période 20 I I-202 I à l'aide de modèles fonctionnels de composants et de la méthode du rapport. Les résultats suggèrent que la taille de la population âgée de 15 ans et plus en Afrique du Sud peut passer de 36,4 millions à la mi-20I I à 42,5 millions en milieu-202I. La province de Gauteng devrait pour avoir le plus grand nombre de personnes dans ce groupe d'âge. Le nombre de ménages à l'échelle nationale devrait pour augmenter de 15 millions à la mi-20II à 20 millions d'ici mi-202I avec Gauteng ayant le plus grand nombre de ménages.

Mots clés: Projections, foyers, logements, municipalités, Afrique du Sud.

\section{Introduction}

Population figures are fundamental to planning in all sectors in any population. Household and dwelling unit figures are also fundamental to planning in certain sectors. The census is the traditional source of this information. From a planning perspective, census figures become out dated immediately they are released because population figures are required for the present and the future.

Households and dwelling units numbers have various uses. From a demographic standpoint, households constitute the unit of sampling in multistage sampling. They are also the unit of listing and enumeration in censuses and the basis for apportioning enumeration areas to enumerators (see for example,
Statistics South Africa: 2007, Laldaparsad: 2009, Mathetha \& Venter: 2007). Because households are often located in dwelling units, information on dwelling units is important. While the unit of analysis in some demographic studies is the household in other studies, their characteristics may constitute contextual explanatory variables (see, Nolunkcwe: 2007, South Africa Institute of Race Relations: 201 I, The Housing Development Agency: 2012). Studies in economics dealing with poverty, income, expenditure and wealth sometimes use households as the unit of analysis (see Woolard \& Klasen: 2004, Leatt: 2006, Leibbrandt et al: 2010). From a social perspective, information on households enables planners to assess future needs for social services such as the provision of water, 
electricity, sewage and refuse disposal as well as housing (see Walsh: 2008). While surveys and censuses may provide information on the current stock, they do not provide information about probable future stock of the population, households and dwelling units.

There is a dearth of studies that project future stock of households and dwelling units in South Africa. Few of the studies include the following. Walsh's (20II) study was only suggestive of the methods that may be used to project the number of households into the future but did not provide projected figures. The study suggested that average household size be used to calculate future number of households from projected population figures. A limitation of this approach is that it does not take into consideration variations in the age pattern in household formation and therefore such approach is likely to produce biased estimates. This is because young persons (below the age of 15 years - who are not at risk of forming new households) are included in the computation of average household size. This approach was utilised in van Aardt's (2007) study. His projections were at national and provincial levels. New data especially the 201I South Africa census have become available since van Aardt's study and hence his projected figures need to be revisited. For example while his projected total population figure on which average household size was applied for 201 I was 48.5 million, the $201 \mathrm{I}$ census results indicated a total population of $5 \mathrm{I} .8$ million as of October $20 \mathrm{I} \mathrm{I}$. It would appear from this that all other things the same, the projected number of households for the projection period in van Aardt's study are underestimates.

Haskins'study utilised data sets from different organisations. The study was confined to Cape Town. It used the annual increase in households between 1996 and $200 \mathrm{I}$ to project the total number of households in 2002-2005 in Cape Town. The limitations of Haskins' study include the following. Different organisations do not employ the same standards in collecting data thus the data sets used may have been of varying quality. The study was limited in time (terminal end of the projection was 2005) and space (confined to Cape Town). The methodology used - annual growth rate to project households does not take into account variations in age pattern in household formation (see the methods section on age pattern of household heads). None of the above studies provides projections of households and dwelling units at district municipality levels yet much of planning takes place at this level and at lower levels.

\section{OBJECTIVES OF THE STUDY}

The primary objective of this study therefore was to provide projections of households and dwelling units from 20 I I-202 I nationally, provincially and by district municipality for South Africa to aid planning at these levels. Since the methodology employed in this study requires projections of the population of a certain age range, a secondary objective was to provide projections of the population aged 15 years and over nationally and provincially from 20 I I-202I for South Africa.

\section{DATA}

For the population estimates, the historical trends in fertility and mortality were based in part, on estimates provided by Udjo (2005a, 2005b, 2008), that utilised the 1996 Census (Statistics South Africa 1998), 1997 and 1998 October Household Survey as well as the 2007 Community Survey data. The 20II South Africa Census (Statistics South Africa 20I2) was used to estimate current levels of fertility, mortality as well as current trends in net migration. The population estimates incorporate HIV/AIDS through the use of the INDEPTH (2004) model life tables.

For the household and dwelling unit projections, the 1996, 200I and 20II censuses (Statistics South Africa 1998, 2003, 2012) data were used, being the three post-apartheid population censuses that have been conducted in South Africa. The overall undercount in the 1996 Census was 11\%, which increased to $18 \%$ in the 2001 Census but decreased to $14.6 \%$ in the 2011 Census. The tabulations of households and dwelling units from these censuses were based on the 20I I provincial boundaries. Several aspects of each of South Africa's post-apartheid censuses are controversial. These controversies have been reported in several studies. See for example, Dorrington (1999), Sadie (1999), Shell (1999), Phillips, Anderson \& Tsebe (1999), (Udjo 1999, 2004a, 2004b). Some of the controversies pertain to the reported age-sex distributions (especially the $0-4$ years age group) and the overall adjusted census figures. A number of the limitations in the data relevant to the present study especially those pertaining to underreporting of fertility and mortality were addressed in Udjo's (2005a, 2005b, 2008) studies and incorporated in this study.

\section{METHODS}

\section{Definitions}

Household: The cooking pot definition is often employed in defining households internationally but the precise definition varies from country to country. According to the multi-lingual demographic dictionary, a household is a group of individuals who share living quarters and their principal meals (van de Walle 1982). The United Nations Economic Commission for Africa (UNECA 1974) defines a household as a group of people who live and eat together. A United Nations Manual, (cited in Casley \& Lury 1989) recommends that the concept of 'household' should be based on the 
arrangements made by persons, individually or in groups, for providing themselves with food or other essentials for living and which may be either a oneperson household or a multi-person household. Statistics South Africa (1998) defines a household as consisting of a single person or a group of people who live together for at least four nights a week, who eat from the same pot and who share resources. These are 'social unit' rather than'physical unit' definitions although a household will usually occupy a physical structure or housing unit. For assessing future needs in housing and social services (such as water and electricity), identification of a physical structure (such as a dwelling or housing unit) is what is needed rather than a social agglomerate of people in time and space.

Dwelling unit: The multi-lingual demographic dictionary defines a dwelling unit as a statistical abstraction denoting housing accommodation appropriate for occupation by one household (Van de Walle 1982). Statistics South Africa defines a dwelling unit as a structure or part of a structure or group of structures occupied or meant to be occupied by one or more than one household. This includes a structure or part of a structure which is vacant and /or under construction but can be lived in at the time of the survey. It also includes units in collective living quarters, unlike a housing unit. Dwelling units may therefore comprise housing units plus units in collective living quarters when applicable. According to Statistics South Africa's definitions, dwelling units include housing units, converted hostels (e.g. family units), residential hotels, homes for the aged, hospitals/medical facilities/clinics, prisons/correctional institutions/police cells, defence force barracks, frail care centres, refugee camps/shelters, convents/monasteries, orphanages/homes for disabled, hotels (including tourist hotel), hostels, student residences/boarding schools (Statistics South Africa 2009).

Housing units constituted about $95 \%$ of all enumerated dwelling units in the 20I I Census. The tabulations from the census data utilised in the computations in this study were based on Statistics South Africa's definitions of a 'household' and 'dwelling unit'.

\section{Projecting the Population}

Household projections involve 'functional' projection. According to (Kono 1993), "functional population projection is an age-sex population projection that has been transformed or otherwise incorporated into formulas that forecast the future supply or demand for some particular purpose". Functional projections at high levels of aggregation involves two stages: a cohort component projection of the population and a cohort component projection of households using the headship rate. The ratio method may then be used to project households at lower levels of disaggregation. These approaches were utilised in the present study as outlined below.

\section{Provincial, National and district municipality population projections}

The cohort component method was used to project the population of each province and the sum of the provincial projections yielded the national total population for each of the projection periods. The base of the projections was the October 201I Population Census figures adjusted to mid-20II using geometric interpolation of the exponential form. The terminal end of the projections is 2021 .

\section{Assumptions in the cohort component provincial population projections}

The cohort component method of population projections entails separate projections of fertility, mortality (taking into account HIV/AIDS) and net migration. The extrapolation of trends in fertility, mortality and net migration was based on certain assumptions. Although it is customary to produce at least three variants - low, medium and high projections embodying different sets of assumptions about fertility mortality and net migration, for brevity and ease of interpretation of results, only the medium variant (which is conventionally interpreted as the most likely scenario) projections are presented in this study. The assumptions underlying the medium variant population projections are summarised in Table I. The basis of the assumptions was the analysis of historical trends and current levels as estimated from various Statistics South Africa data sets. These include the 1995 and 1998 October Household Surveys (Statistics South Africa 1996, 1999), the 1996 Census (see Udjo 2005a, 2005b), 2007 Community Survey (Statistics South Africa 2008), $200 \mathrm{I}$ and $20 \mathrm{II}$ Censuses (Statistics South Africa 2003, 2013). The trends in fertility, mortality were then extrapolated to 2021. The linear extrapolation took into consideration the present state of demographic knowledge such that lower and upper limits had to be set for the end of the projection period. The assumptions about net migration were based on the magnitude and trend estimated from the 20I I Census extrapolated to 2021 . 
Table I: Assumptions in the Provincial Population Estimates

\begin{tabular}{|c|c|c|c|c|c|c|}
\hline & \multicolumn{3}{|l|}{2011} & \multicolumn{3}{|l|}{2021} \\
\hline & TFR & $\mathbf{E}_{0}$ & Net Mig & TFR & $\mathbf{E}_{0}$ & Net Mig \\
\hline Eastern Cape & 2.8 & 50.4 & -9278 & 2.38 & 52.5 & 24060 \\
\hline Free State & 2.5 & 53.6 & -1814 & 2.33 & 55.6 & 33196 \\
\hline Gauteng & 2.4 & 59.9 & 31698 & 2.40 & 61.8 & 137139 \\
\hline KwaZulu-Natal & 2.7 & 50.3 & $-|268|$ & 2.37 & 52.4 & 54358 \\
\hline Limpopo & 3.1 & 57.2 & 1801 & 2.43 & 59.2 & 90593 \\
\hline Mpumalanga & 2.9 & 56.2 & 541 & 2.40 & 58.2 & 45362 \\
\hline Northern Cape & 2.8 & 59.7 & -1323 & 2.38 & 61.8 & 615 \\
\hline North West & 2.9 & 59.0 & 2499 & 2.40 & 60.9 & 547714 \\
\hline Western Cape & 2.4 & 66.0 & 3137 & 2.15 & 68.1 & 43101 \\
\hline
\end{tabular}

TFR = Total fertility rate; $E_{0}=$ Life expectancy at birth (years, both sexes); Net Mig $=$ Net migration (Internal and international)

\section{District municipality population projections}

The ratio method was used in projecting the district municipality populations and consisted of the following steps. Firstly, within each province, population ratios of district municipalities to the provincial population based on the 1996, $200 \mathrm{I}$ and $20 \mathrm{II}$ censuses and based on the 20I I provincial boundaries were computed for all district municipalities. Secondly, the population ratios were linearly extrapolated to $202 \mathrm{I}$. In order to obtain the population estimates for each of the district municipalities, the result of the extrapolated ratio for each time period within the projection period for each district municipality was applied to the provincial population estimates for each time period. The advantage of this approach is that it is not necessary to estimate and project trends in fertility, mortality and net migration at district municipality level where the data are more limited. The approach indirectly takes into account fertility, mortality and net migration because the growth (positive or negative) and hence the size of each district population is due to fertility, mortality and net migration.

For each district municipality, the projection may be expressed algebraically as

$P(i, j, t)=P(j, t) * r(i, t)$

Where $P(i, j, t)$ is a projected district municipality $i$, population in a province $j$, in a specific time period $t$, $P(j, t)$ is a projected provincial $j$, population at time $t$ and $r(i, t)$ is a projected ratio of district municipality population to its projected provincial population at time $t$.

\section{Household Projections}

\section{National and provincial household projections}

The cohort component functional model of household projections may be expressed as
$H H(x, s, j, t+n)=P(x, s, j, t+n) . H R(x, s, j, t, n)$

Where:

$x$ is a five-year age group starting at 15 or the open ended age group which is 65 years in this study. Although some persons aged $10-14$ were reported as household heads, the percentages were negligible $(0.41 \%$ at national level in $20 \mathrm{II})$ and were excluded from the analysis. Although in some cases, it might be true that some persons aged 10-14 may be household head, it might also be a reflection of the quality of the data. Conventionally however, the age group $15+$ is used.

$s$ is sex;

$j$ is a province;

$t$ is the initial time period;

$t+n$ is the end of the time period interval;

$H H_{(t+n)}$ is the estimated number of household heads (equivalent to the number of households) at the midpoint of the interval;

$P_{(t+n)}$ is the projected number of persons in the population at the mid-point of the interval,

$H R_{(t, n)}$ is the projected headship rate during the interval.

Thus, a cohort component model of functional household projections for each province in this study is therefore expressed as:

$$
H H=\sum_{x=15}^{64,65+}\left(P_{s, x} . H R_{s, x}\right)
$$

where $H H$ is the sum of the number of household heads in each five-year age group from 15-64 and the open age interval, 65 years and above for a sex group (i.e. number of households whose heads are in the age-sex group specified). The sum of all the projected provincial households for each period yielded the 
national total of households for the period. The period for the household projections is 201I-202I.

The Headship rates used in this study were based on the linear extrapolation of the rates observed in 1996, 2001 and 2011 to 2021 . The rates observed in 1996, 2001 and 201 I for males at national level are illustrated in figure 2 . The headship rates exhibit a distinct age pattern that increase sharply after age 15 and taper off after age 30-34 for males. The increase in headship rates for females was more or less exponential after age 15 (graph not shown).

Figure 2: Male headship rates by age group, South Africa 1996, 200 I, 20 I I

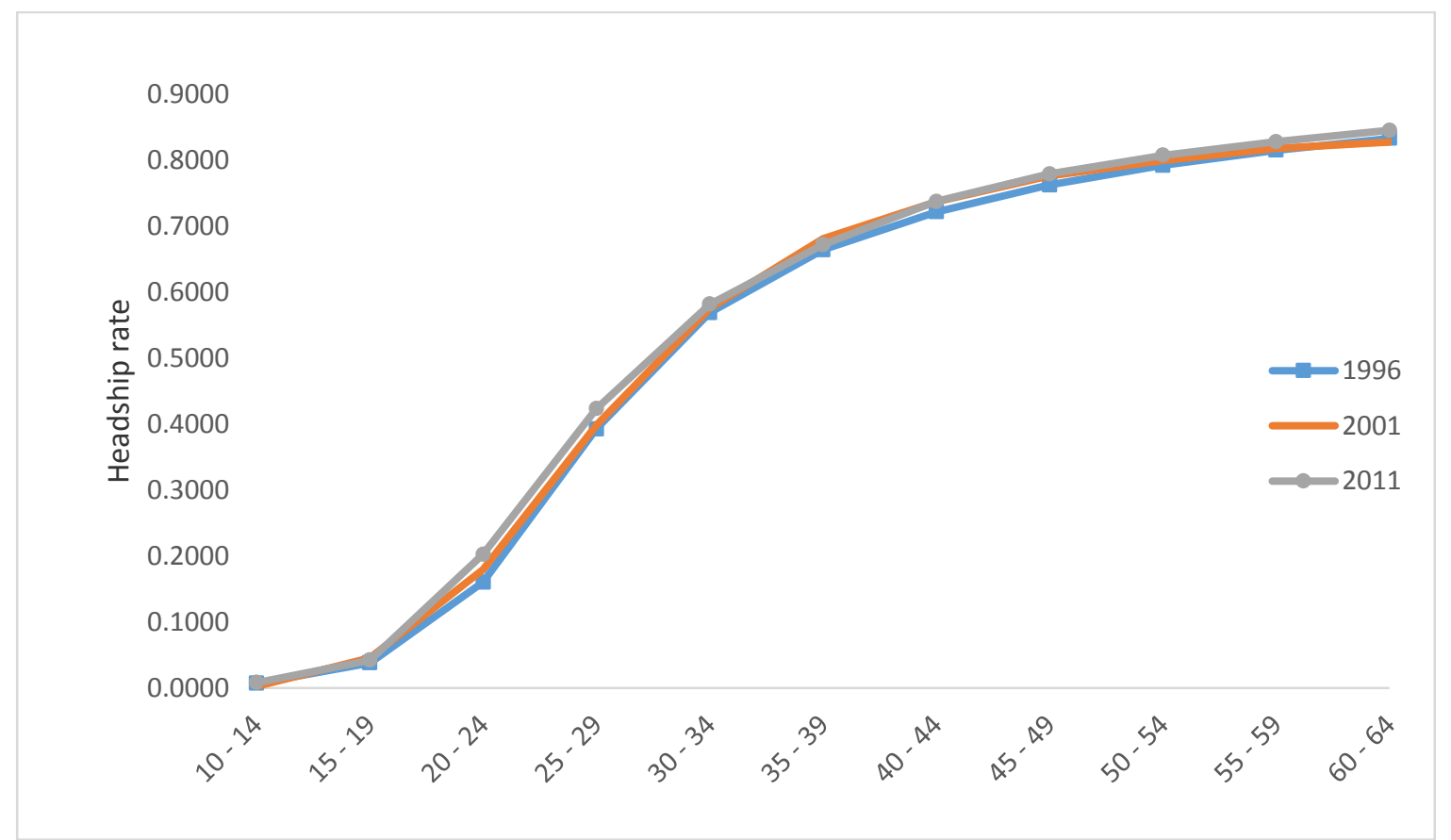

Source: Author's computation from raw census data

\section{District municipality household projections}

In theory, one could apply the cohort component model of functional household projections to district municipality household projections but this is computationally heavy and tedious. Also, the data required to do this are sparser and less reliable at this level. Hence the ratio method was applied as follows. Within each province, household head ratios in district municipalities to total provincial household heads in 1996, $200 \mathrm{I}$ and $201 \mathrm{I}$ censuses were computed for all district municipalities based on the $201 \mathrm{I}$ provincial boundaries. Secondly, the computed household head ratios were linearly extrapolated to 202I. In order to obtain estimates of the number of households for each of the district municipalities from mid-2012 to mid2021 , the result of the extrapolated ratio for each period for each district municipality was applied to the total provincial household estimates for the period. The method may be expressed algebraically as:

$H H_{(i, j, t)}=H H_{(i, t)} * p_{(i, t)}$

Where $H H_{(i, j, t)}$ is a projected district municipality $i$, number of household heads in a province $j$, in a specific time period $t, H H_{(j, t)}$ is a projected provincial $j$, number of household heads at time $t$ and $p_{(i, t)}$ is a projected ratio of district municipality number of household heads to its projected provincial number of household heads at time $t$.

Assumptions in the district municipality projections The underlying assumption in the district municipality household projections was that the trend in the ratio of household heads in district municipalities to total provincial household heads in 20I2-202I will be similar to the trend observed in the ratios in 1996, $200 \mathrm{I}$ and $201 \mathrm{I}$.

\section{Dwelling Units Projections}

The ratio method was used in all the dwelling unit projections as follows.

\section{Provincial and National dwelling unit projections}

The base count of the dwelling units used in the estimation was the aggregated number of enumerated dwelling units based on the following questions: Which type of dwelling does this household occupy? (1996 Census). What is the type of these living quarters? (200I and 20II Censuses). At the provincial level and for each province, the ratio of the total number of dwelling units to housing units in 1996, 200I and 20II were computed from the census data based on the 
201 I provincial boundaries. The ratios for $200 \mathrm{I}$ and 201 I were then linearly extrapolated to 202I (the ratios for 1996 were much higher and inconsistent with those for $200 \mathrm{I}$ and 20II). The result of the extrapolated ratios for each province was applied to the estimated total provincial number of household heads for the period to obtain the total number of dwelling units in a province for each period in the projection interval. The method may be expressed algebraically as:

$$
D U_{(j, t)}=H H_{(j, t)} * R_{(i, t)}
$$

Where $D U_{(j, t)}$ is a projected number of dwelling units in a province $j$, in a specific time period $t, H H_{(j, t)}$ is a projected number of household heads in a province at time $t$ and $R_{(i, t)}$ is a projected ratio of the total number of dwelling units to housing units in the province at time $t$. The sum of the projected dwelling units for all provinces for each period yielded the national total number of dwelling units for the period.

\section{District municipality dwelling unit projections}

Regarding district municipalities in each province, the ratio of dwelling units in a municipality to the total provincial dwelling units in $1996200 \mathrm{I}$ and $201 \mathrm{I}$ were computed. These ratios were linearly extrapolated to 202I. To obtain the total number dwelling units in a district municipality, the extrapolated ratios for each period was applied to its estimated total provincial number of dwelling units for the period. The method may be expressed algebraically as:

$$
d u_{(i, j, t)}=D U_{(j, t)} * R_{(i, t)}
$$

Where $d u_{(i, j, t)}$ is a projected district municipality $i$, number of dwelling units in a province $j$, in a specific time period $t, D U_{(j, t)}$ is a projected provincial $j$, number of dwelling unts at time $t$ and $R_{(i, t)}$ is a projected ratio of dwelling units in a municipality to its projected total provincial dwelling units at time $t$.

\section{Assumptions in the dwelling unit projections}

The assumptions underlying the dwelling unit projections were: (I) the trend in the ratio of the total number of provincial dwelling units to housing units in 20I2-202I will be similar to the trend observed in the ratios in 200 I and 20I I; (2) the trend in the ratio of dwelling units in a district municipality to the total provincial dwelling units in 2012-202 I will be similar to the trend observed in the ratios in 1996, $200 \mathrm{I}$ and 2011 .

\section{RESULTS \\ PROJECTED POPULATION \\ Projected National and Provincial Population (aged I 5 years and over) 20 I I-202 I}

The annual rate of population growth resulting from age-sex cohort changes provides an overall measure of the balance in the components of population growth. Figure I summarises the projected growth rate in the population aged 15 years and over. Persons aged 15 years and over in the context of this study constitute the 'population at risk of becoming household heads' (though a negligible percentage of persons aged 10-14 may be household heads). The graph suggests that if the assumptions underlying the population projections hold, annual growth of the population aged 15 years and over nationally may increase from about $1.4 \%$ during the period $20 \mathrm{I} \mathrm{I}-20 \mathrm{I} 2$ to about $2.0 \%$ during the period 2020-202I. 
Figure I: Projected annual percentage growth rate of the population aged 15 years and over by province

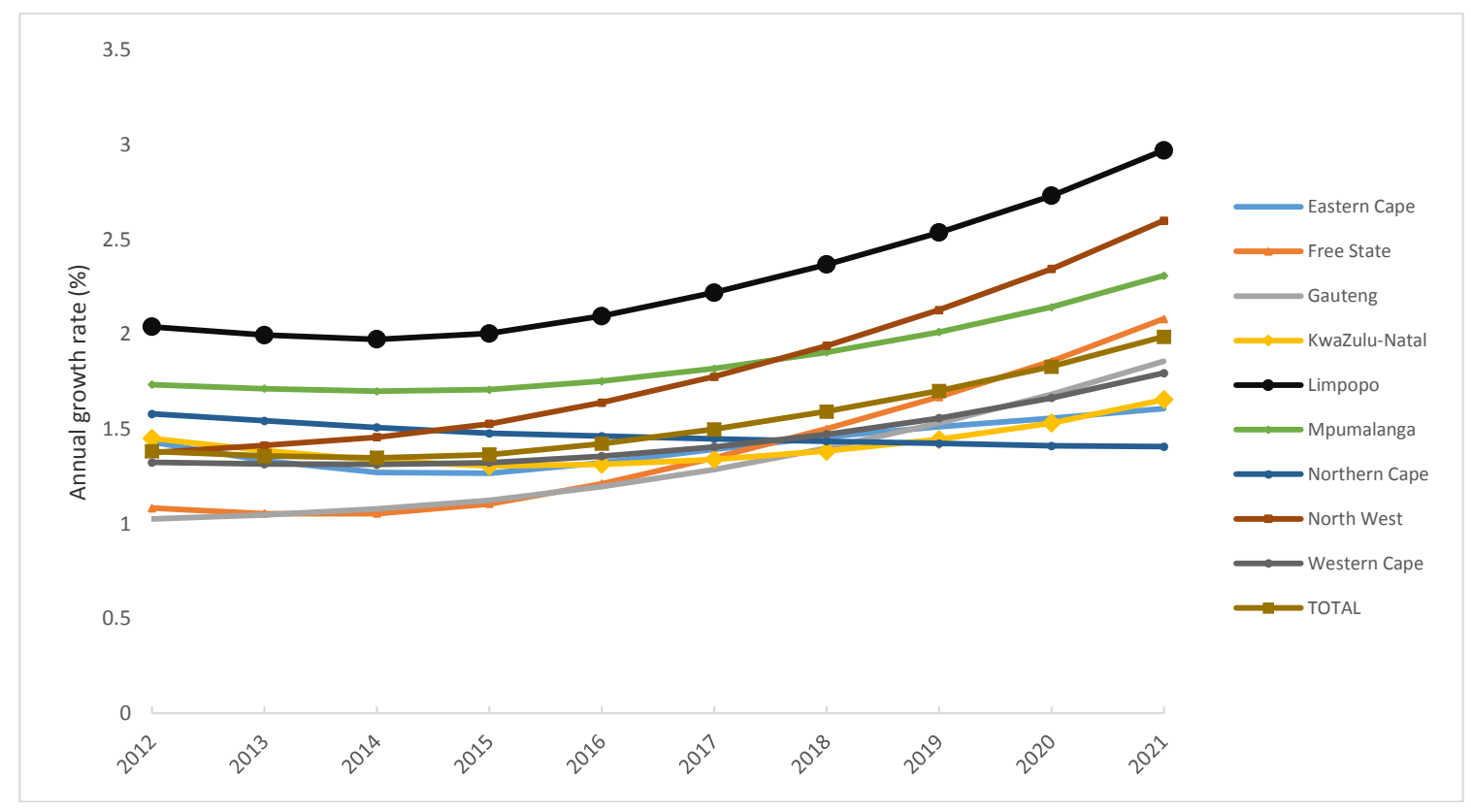

Source: Author's estimation

Limpopo province is projected to have the highest annual growth rate of the population aged 15 years and over during the projection period - increasing from $2.0 \%$ during the period $20 \mathrm{II}-20 \mathrm{I} 2$ to $3.0 \%$ during the period 2020-202I. Gauteng is projected to have the lowest annual growth rate during the period 20I I-2017. The Northern Cape is projected to have the lowest annual growth during the period 20182021 .
In absolute terms, it is projected that the population aged 15 years and over nationally may increase from about 36.4 million in mid-20II to about 42.5 million in mid-202I. Gauteng province is projected to have the largest number of persons in this age group - increasing from about 9.3 million in mid$20 \mathrm{II}$ to about 10.6 million in mid-202I with the Northern Cape projected to have the least number of persons in this age group during the projection period (see Table 2). 
Table 2: Projected population aged 15 years and over by province at mid-year

\section{Eastern Cape Free State}

\begin{tabular}{|c|c|c|c|c|c|c|c|c|c|c|}
\hline 2011 & $4,378,888$ & $|, 943,72|$ & $9,277,421$ & $6,959,54 \mathrm{I}$ & $3,549,699$ & $2,755,050$ & 795,680 & $2,453,809$ & $4,316,935$ & $36,430,744$ \\
\hline 2012 & $4,442,014$ & $1,964,885$ & $9,373,033$ & $7,06 \mathrm{I}, 288$ & $3,622,853$ & $2,803,262$ & 808,357 & $2,487,828$ & $4,374,47$ I & $36,937,991$ \\
\hline 2013 & $4,501,666$ & I,985,706 & $9,471,635$ & $7,159,892$ & $3,695,912$ & $2,85 \mathrm{I}, 734$ & 820,933 & $2,523,244$ & $4,432,396$ & $37,443,118$ \\
\hline 2014 & $4,559,267$ & $2,006,760$ & $9,574,395$ & $7,256,113$ & $3,769,586$ & $2,900,627$ & 833,413 & $2,560,305$ & $4,491,019$ & $37,95 I, 485$ \\
\hline 2015 & $4,617,460$ & $2,029,068$ & $9,682,606$ & $7,35 I, 532$ & $3,845,929$ & $2,950,614$ & 845,818 & $2,599,743$ & $4,550,852$ & $38,473,622$ \\
\hline 2016 & $4,678,936$ & $2,053,826$ & $9,799,198$ & $7,448,787$ & $3,927,432$ & $3,002,817$ & 858,283 & $2,642,74 \mathrm{I}$ & $4,613,040$ & $39,025,060$ \\
\hline 2017 & $4,744,543$ & $2,081,694$ & $9,926,165$ & $7,549,260$ & $4,015,633$ & $3,057,938$ & 870,814 & $2,690,124$ & $4,678,360$ & $39,6|4,53|$ \\
\hline 2018 & $4,8 \mid 4,327$ & $2,113,180$ & $|0,066,04|$ & $7,654,439$ & $4,|I|, 92 I$ & $3,116,777$ & 883,416 & $2,742,822$ & $4,747,779$ & $40,250,702$ \\
\hline 2019 & $4,887,740$ & $2,|48,76|$ & $10,22 \mid, 424$ & $7,765,933$ & $4,217,589$ & $3,180,149$ & 896,089 & $2,80 I, 826$ & $4,822,356$ & $40,94 I, 867$ \\
\hline 2020 & $4,964,416$ & $2,189,057$ & $10,395,017$ & $7,885,88$ I & $4,334,395$ & $3,249,070$ & 908,834 & $2,868,318$ & $4,903,292$ & $41,698,280$ \\
\hline 2021 & $5,044,926$ & $2,235,117$ & $10,590,013$ & $8,017,598$ & $4,465,121$ & $3,325,025$ & 921,719 & $2,943,892$ & $4,992,165$ & $42,535,576$ \\
\hline
\end{tabular}




\section{PROJECTED HOUSEHOLDS}

Projected National and Provincial households 20II-202I

\section{Projected Growth Rates}

The average annual growth in the number of households nationally is projected to increase from about $2.9 \%$ per annum during the period $2011 / 2016$ to about $3.0 \%$ per annum during the period $2016 / 2021$. At provincial level, the growth rate in the periods 2011/2016 and 2016/2021 showed three patterns: (I) an increase in the average annual growth in the number of households (ranging from about $1.7 \%-3.2 \%$ in $2011 / 2016$ to $3.2 \%-3.8 \%$ in $2016 / 2021$ ). The provinces in this category are the Eastern Cape, Free State, Limpopo, Mpumalanga and North West. (2) A decline in the average annual growth in the number of households in, Gauteng, Northern Cape and Western Cape (ranging from about $2.4 \%-3.4 \%$ in $2011 / 2016$ to $2.2 \%-3.1 \%$ in
2016/202I). (3) A stable average annual growth rate in the number of households in KwaZulu-Natal (about $2.8 \%$ in 2011/2016 and 2016/202). Gauteng, Mpumalanga, Limpopo and North West are projected to have the highest annual growth rate (about $3 \%$ or higher) in the number of households.

Projected Absolute numbers of households and average household size

The absolute numbers of projected households are shown in table 3. In absolute terms, it is projected that the number of households nationally may increase from about I 5 million in mid-20II to about 20 million in mid-2021. Gauteng province is projected to have the highest number of households - increasing from about 4.1 million in mid-20II to about 5.7 million in mid-202I with the Northern Cape projected to have the least number of households - increasing from about 315,000 in mid-20II to about 396,000 in mid2021 . 
Table 3: Projected number of households by province at mid-year

\section{Eastern Cape Free State Gauteng KwaZulu-Natal}

\begin{tabular}{|c|c|c|c|c|c|c|c|c|c|c|}
\hline 2012 & $\mathrm{I}, 779,086$ & 868,177 & $4,254,181$ & $2,660,37 \mathrm{I}$ & $I, 5 \mid 8,456$ & $\mathrm{I}, \mathrm{I} 57,500$ & 322,569 & $1,089,967$ & $\mathrm{I}, 745,749$ & $15,396,056$ \\
\hline 2013 & $1,809,609$ & 893,163 & $4,403,150$ & $2,734,80 \mathrm{I}$ & $1,563,682$ & $1,195,133$ & 330,271 & $\mathrm{I}, \mathrm{I} 25,090$ & $\mathrm{I}, 792,550$ & $15,847,449$ \\
\hline 2014 & I,840,656 & 918,869 & $4,557,336$ & $2,8|I, 3| 4$ & $1,610,256$ & $1,233,990$ & 338,157 & $\mathrm{I}, 161,344$ & $\mathrm{I}, 840,607$ & $16,312,529$ \\
\hline 2015 & $\mathrm{I}, 872,235$ & 945,314 & $4,716,922$ & $2,889,967$ & $1,658,217$ & $1,274,110$ & 346,231 & $\mathrm{I}, 198,767$ & I,889,95। & $|6,79|, 7 \mid 4$ \\
\hline 2016 & $1,904,356$ & 972,520 & $4,882,095$ & $2,970,820$ & I,707,606 & I,3।5,535 & 354,498 & I,237,395 & $1,940,619$ & $17,285,444$ \\
\hline 2017 & $1,943,806$ & $\mathrm{I}, 004,237$ & $5,034,516$ & $3,056,292$ & $\mathrm{I}, 773,833$ & $1,362,359$ & 362,399 & $I, 283,39 \mid$ & $1,988,692$ & $17,809,525$ \\
\hline 2018 & I,984,074 & $1,036,988$ & $5,191,695$ & $3,144,224$ & $1,842,628$ & $\mathrm{I}, 410,850$ & 370,477 & I,33I,096 & $2,037,955$ & $18,349,987$ \\
\hline 2019 & $2,025,176$ & $\mathrm{I}, 070,808$ & $5,353,78 \mathrm{I}$ & $3,234,685$ & $|, 9| 4,09 \mid$ & $|, 46|, 067$ & 378,735 & I,380,575 & $2,088,439$ & $18,907,357$ \\
\hline 2020 & $2,067,129$ & $\mathrm{I}, 105,73 \mathrm{I}$ & $5,520,928$ & $3,327,749$ & $1,988,325$ & $\mathrm{I}, 5 \mathrm{I}, 072$ & 387,176 & I,43I,893 & $2,140,173$ & $19,482,176$ \\
\hline 2021 & $2,|09,95|$ & $\mathrm{I}, 14 \mathrm{I}, 792$ & $5,693,293$ & $3,423,491$ & $2,065,439$ & $1,566,927$ & 395,806 & I,485, II8 & $2,193,189$ & $20,075,006$ \\
\hline
\end{tabular}


The projections indicate that average household size (the number of persons per household) may decline. At the national level, average household size is projected to decrease from about 3.4 persons per household in $201 \mathrm{I}$ to about 2.9 persons per household by $202 \mathrm{I}$. KwaZulu-Natal is projected to have the highest average household size -4.0 in 2011, 3.6 in 2016 and 3.3 by 2021 - while Gauteng the lowest 3.0 in 20II, 2.7 in 2016 and 2.5 by 2021 . Projected household size by 2021 in other provinces are: Eastern Cape (3.3), Free State (2.7), Limpopo (3.1), Mpumalanga (3.0), Northern Cape (3.2), North West (2.7) and Western Cape (3.0).

\section{Projected Sex composition of Household Heads}

At the base period (20I I), the Eastern Cape Province had the highest percentage $(50.3 \%)$ of households that were headed by females in comparison with other provinces. This is higher than the national average of 40.9\%. Limpopo and KwaZulu-Natal provinces also had higher percentages of households that were headed by females than the national average in $201 \mathrm{l}$. Gauteng province had the lowest percentage (34\%) of households headed by females in comparison with other provinces in 20ll. It is projected that the percentage of households headed by females may decline in the Eastern Cape (from 50.3\% in 201 I to $48.6 \%$ in 2021 ), Limpopo (from $49.5 \%$ in 201 I to $44.1 \%$ in $202 \mathrm{I}$ ), Mpumalanga (from $40.1 \%$ in $201 \mathrm{I}$ to $38.6 \%$ in $202 \mathrm{I}$ ) and North West (from $36 \%$ in 201 I to $33.8 \%$ in 2021 ). In the other provinces, the percentage may either increase (KwaZulu-Natal, the Northern Cape, the Western Cape, Gauteng) or remain more or less stable (the Free State). Consequently, KwaZulu-Natal is projected to have the highest percentage $(48.7 \%)$ of households that are headed by females by 2021 .

\section{Median age of household heads}

The median is a useful measure of the age composition of household heads. In general, the projections indicate that female heads of households are older on average (46.8 years in $20 \mathrm{II}$ and 48.2 years in 202I) than male heads of households (4I.9 years in 2011 and 43.1 years in 202I). At the national level, female heads of households were about 4.9 years older than male heads of households in 2011 . This age gap is projected to widen slightly to 5.1 years by 202 I nationally. The higher median age for females is partly due to widowhood. In every human population, the force of mortality is higher among males than females. Consequently, some females would become heads of household at the death of their spouse/partner.

At provincial level, the Eastern Cape had the highest median age ( 50.2 years) of female household heads in $201 \mathrm{I}$ and is also projected to have the highest median age (5I.I years) of female household heads by 2021 in comparison with other provinces. Gauteng had the lowest median age (43.5 years) in $20 \mathrm{II}$ and is also projected to have the lowest median age (46.4 years) of female household heads by 2021 in comparison with other provinces.

The median age of female household heads is projected to increase in the Northern Cape, Western Cape, North West, Free State and Mpumalanga while it is projected to decrease in the Eastern Cape and Limpopo. The median age of male household heads is projected to increase in all provinces except in KwaZulu-Natal where it is projected to be more or less stable, as among female household heads in the province.

\section{Projected Households in District Municipalities 2021.}

Figure 3 shows the results of the projected number of households in district municipalities ranked from the lowest to the highest by 202I. It is projected that of all the district municipalities in the country, the Central Karoo district municipality located in the Western Cape would have the lowest number of households $(24,175)$ by 2021 , while the City of Johannesburg located in Gauteng would have the highest number of households $(2,158,528)$ by 2021 . 
Figure 3: Projected number of households in district municipalities by 202 I

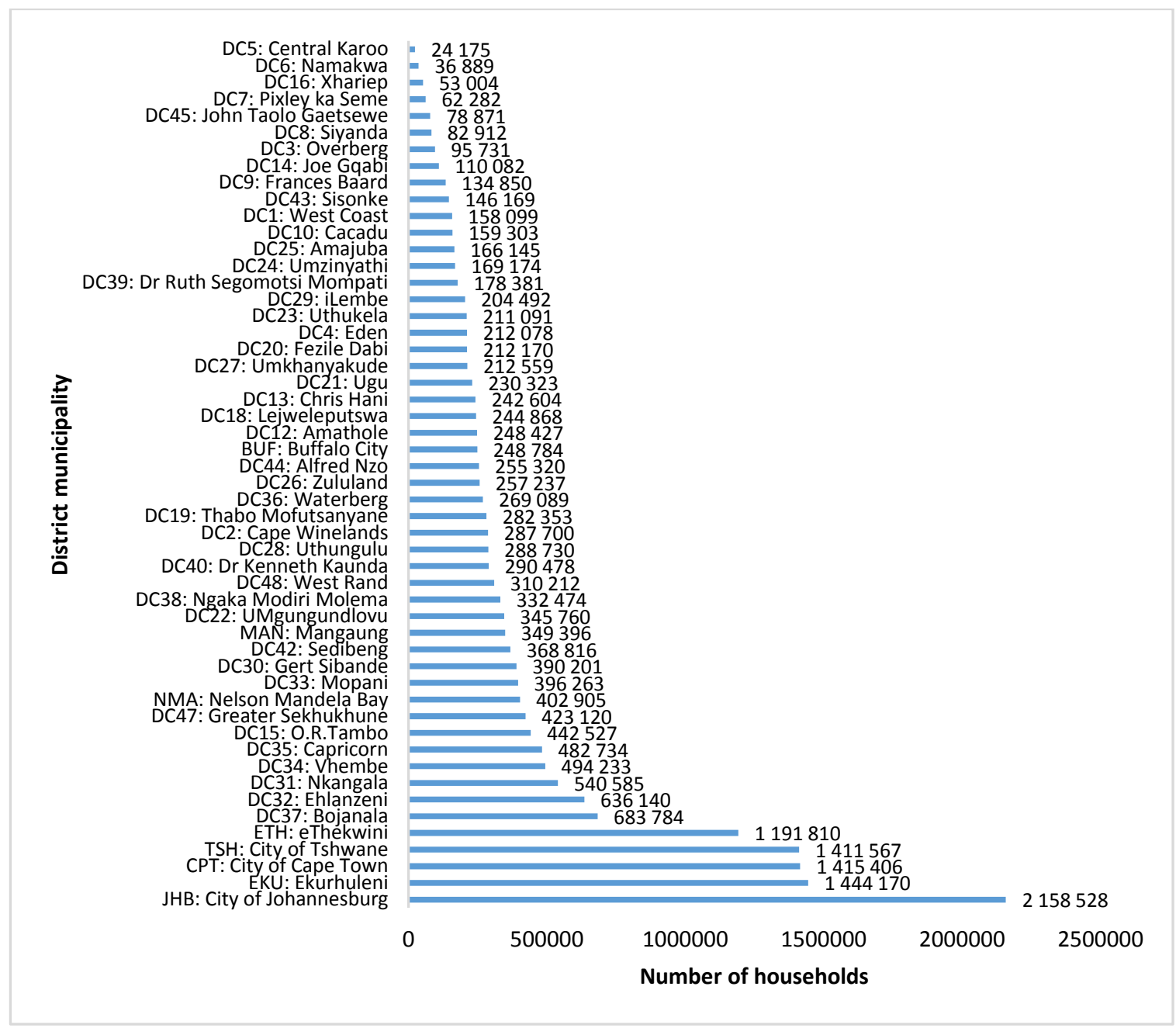

Source: Author's estimation

\section{PROJECTED DWELLING UNITS}

Projected national and provincial numbers of dwelling units

Table 4 summarises the results of the projected number of dwelling units at national and provincial levels. As seen in the table, it is projected that the number of dwelling units nationally will increase from about 15.8 million in 2011 to about 21.3 million in 2021. This implies an average annual growth rate of about 3.0\% per annum during the period 20II-202I. Gauteng is projected to have the highest number of dwelling units (6.2 million) by 2021 , implying an average annual growth rate of about $3.0 \%$ per annum during the period 20II-202I. The Northern Cape is projected to have the lowest number of dwelling units $(417,798)$ by 2021 , implying an average annual growth rate of about $2.3 \%$ per annum during the period. 
Table 4: Projected number of dwelling units by province

2011

I,834,890

869,382

$4,442,150$

$2,728,042$

I,525, 104

I,I66,965

332,051

I, 104,438

I,783,475

I5,786,496
2021

$2,281,39 \mid$

$1, \mid 69,911$

$6,230,997$

$3,632,092$

$2,102,288$

$1,617,265$

417,798

$|, 556,88|$

$2,336,140$

$21,344,764$

Average annual growth rate

2.2

3.0

3.4

2.9

3.2

3.3

2.3

3.4

2.7

3.0

Source: Author's estimation

Projected numbers of dwelling units in district municipalities

Figure 4 shows the results of the projected number of dwelling units in district municipalities ranked from the lowest to the highest by 202I. It is projected that of all the district municipalities in the country, the Central Karoo district municipality located in the Western Cape may have the lowest number of dwelling units $(22,920)$ by 2021 , while the City of Johannesburg located in Gauteng may have the highest number of dwelling units $(2,381,235)$ by 2021 . 
Figure 4: Projected number of dwelling units in district municipalities by $202 \mathrm{I}$

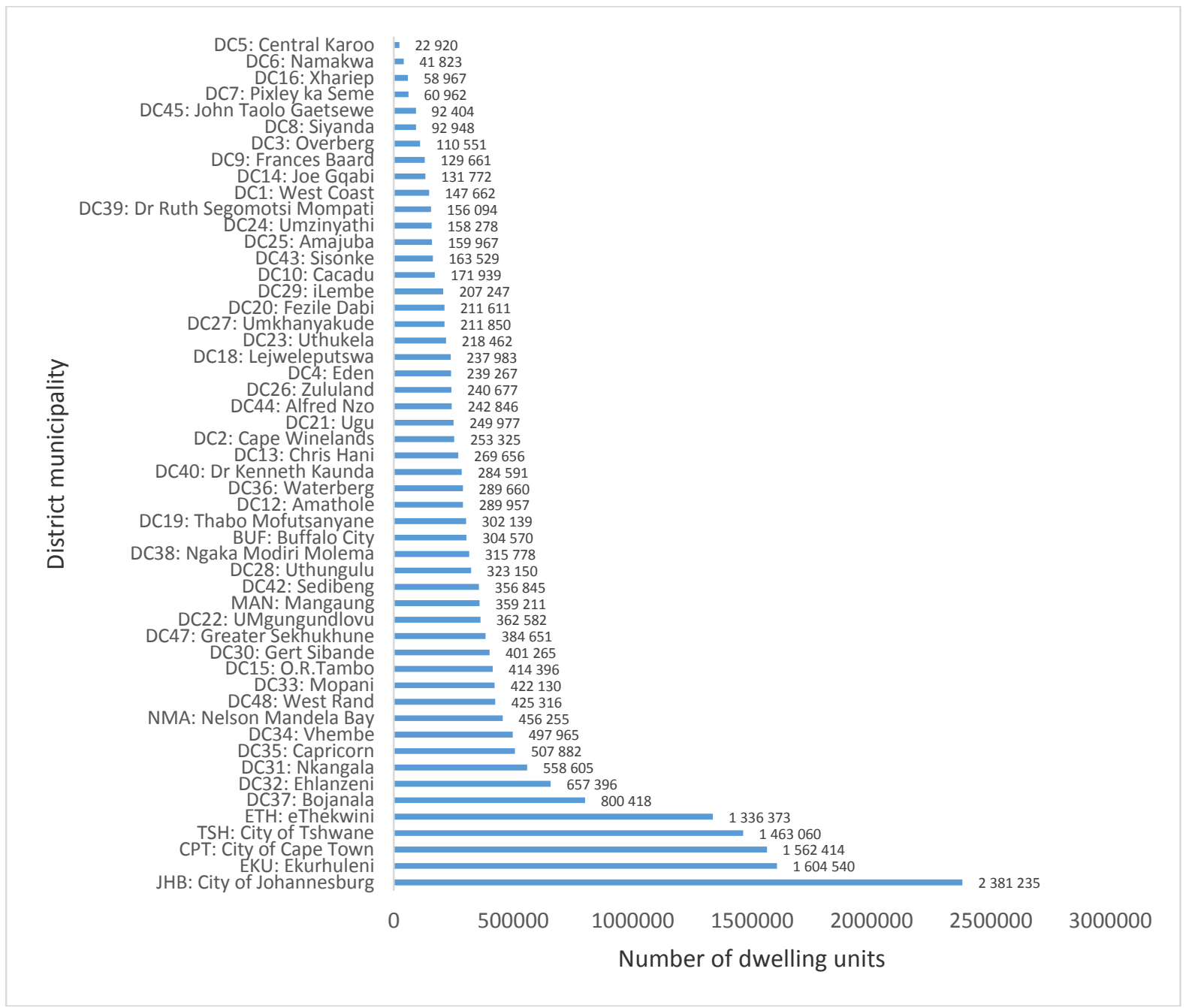

Source: Author's estimation

\section{DISCUSSION, IMPLICATIONS FOR PLANNING AND CONCLUSION}

There is very limited information with which to compare the results of this study due to a dearth of studies on household projections in South Africa. The few available studies suggest approaches that may be used in household projections without providing projected household numbers. Statistics South Africa, the provider of official statistics in South Africa has never undertaken household or dwelling units projections.

One study however, with which to compare the results of this study with is van Aardt's (2007) study which provided household projections up to 202I. Whereas van Aardt projected the number of households to be $17,379,366$ by 2021 , this study projects $20,075,006$ households by 2021 . The differences in the numbers projected numbers lie in methodology and data. Whereas van Aardt's study used average household size for the projections, this study utilised the cohort component functional approach. Newer data have become available since van Aardt's projections. Furthermore, van Aardt's projections were at national and provincial levels and did not project dwelling units. This study projected households and dwelling units at national, provincial and district municipality levels. Our knowledge of households and dwelling units projections in the context of South Africa is therefore enhanced by this study. The results from this study should aid planning in some sectors at lower geographical levels in South Africa.

The results have socioeconomic implications in different sectors nationally, provincially and in district municipalities. Increasing numbers of households and dwelling units imply that in the future, there would be increased demand for electricity, water supply as well as toilet and waste disposal facilities. This needs to be taken into consideration in planning in these sectors. For example the implication of the projections for the Electricity Supply Commission of South Africa (ESKOM - the main supplier of electricity for South African households) entails among others, the following. In planning for energy supply for dwelling 
units by 2021 , the company would have to take into consideration the current load of backlog as at 2014 (i.e. the total number of dwelling units that have applied for electricity connection but still not connected as at 2014). On top of this load, the company would have to take into consideration the projected number of new dwelling units (which is the projected number of dwelling units by 2021 minus the projected number of dwelling units as at 20l4). The sum of these two numbers (i.e. backlog load at a specific time period plus the projected number of new dwelling units by the end of the projection period) constitutes the increase in future demand for electricity. This scenario applies to other social service sectors as well at any level of geographical disaggregation. Aside these socioeconomic implications, the results should inform planning for the next census in South Africa with regard to housing and dwelling units listing, demarcation of enumerator areas as the figures provide some indications of the expected workload in these regard.

It should be noted, that in this study, all types of dwelling or housing units were lumped together in the projections as the focus of the study was not on quality of dwelling or housing units but on numbers. Thus, informal dwellings (such as shacks) and formal dwellings or housing units were given the same treatment in this study. This is perhaps a weakness of the study. Lumping different types of dwelling or housing units together may be unsatisfactory as this may be of concern to certain sectors such as electricity supply (e.g. ESKOM) and government departments such as the Department of Human Settlement from a planning perspective. Although computationally heavy, future studies may consider doing the projections by type of housing and dwelling units.

\section{REFERENCES}

Casley, D.J., Lury, D.A. 1989. Data collection in developing countries. Oxford: Clarendon Press: 163.

Dorrington, R. 1999. To count or to model, that is not the question: some possible deficiencies with the 1996 Census results. Paper presented at the Arminel Roundtable Workshop on the 1996 South Africa Census, Hogsback, 9-I I April.

Hall, K., Meintjes, H. 2013. Children living with parents. Available at http://childrencount.ci.org.za/indicator.php?id = I \& indicator $=2$ Accessed February 202014.

Haskins, C., 2006. Household numbers in Cape Town - Discussion document. Available at http://www.capetown.gov.za/en/stats/CityReports /Documents/Households/Household_Numbers in Cape_Town_162006949I5 359.pdf Accessed February 20 20I4. Accessed February 202014.
Housing Development Agency. 2012. South Africa: Informal settlements status. Available at http://www.thehda.co.za/uploads/images/HDA In formal settlements status South Africa.pdf Accessed February 202014.

INDEPTH Network. 2004. INDEPTH model life tables for sub-Saharan Africa. Aldershot: Ashgate Publishing Limited.

Laldaparsad, S. 2007. A dwelling frame for conducting censuses and surveys. Available at

https://www.sabs.co.za/content/uploads/files/Sharthi \%20Laldaparsad\%20DF\%20SABS.pdf Accessed February 202014.

Kono, S. 1993. Functional population projections. In, Readings in population Research Methodology, vol 5, UNFPA.

Mathetha, M., Venter, C.J. 2007. Forecasting household car ownership in South Africa: alternative models and future trends. Available at http://repository.up.ac.za/handle/2263/5584

Accessed February 202014 Accessed February 20 2014.

Nolunkcwe. B. 2007. Child nutritional status and household patterns in South Africa. Available at http://repository.up.ac.za/handle/2263/5895

Accessed February 202014.

Phillips, H.E., Anderson, B.A., Tsebe, P. 1999. Sex ratios in South African census data 1970 - 1996. Paper presented at the Workshop on Phase 2 of Census 1996 Review on Behalf of the Statistical Council, Wanderers Club, Johannesburg, 3-4 December.

Sadie, J.L. 1999. The missing millions. Paper presented to NEDLAC meeting. Johannesburg.

Shell, R. 1999. An investigation into the reported sex composition of the South African population according to the Census of 1996. Paper presented at the Workshop on Phase 2 of Census 1996 Review on Behalf of the Statistical Council, Wanderers Club, Johannesburg 3-4 December.

Statistics South Africa. 1998. The people of South Africa Population Census 1996: Census in brief. Pretoria.

Statistics South Africa. 1999. 1998 October Household Surveys. Pretoria.

Statistics South Africa. 2003. Census 200I: Census in brief. Pretoria.

Statistics South Africa. 2008. 2007 Community Survey. Pretoria.

Statistics South Africa. 2009. Concepts and definitions for Statistics South Africa. Pretoria.

Statistics South Africa. 2012. Census 201 I: Highlights of key results. Pretoria.

South Africa Institute of Race Relations. 20I I. Living conditions and communications. Available at

http://www.sairr.org.za/services/publications/southafrica-survey/south-africa-survey-online-2009- 
2010/living-conditions-and-communications

Accessed February 202014.

Udjo, E.O. 1999. Comment on R Dorrington's To count or to model, that is not the question. Paper presented at the Arminel Roundtable Workshop on the 1996 South African Census Hogsback 9-1I April. 41

Udjo, E.O. 2004a. Comment on T Moultrie and R Dorrington: Estimation of fertility from the 200I South Africa Census data. Statistics South Africa Workshop on the 200I Population Census.

Udjo, E.O. 2004b. Comment on R Dorrington T Moultrie \& I Timaeus: Estimation of mortality using the South Africa Census 2001 data. Statistics South Africa Workshop on the 200I Population Census.

Udjo, E.O. 2005a. Fertility levels differentials and trends in South Africa in The demography of South Africa edited by T Zuberi, A Simbanda \& E Udjo. New York: M. E. Sharpe Inc Publisher: 40-64.

Udjo, E.O. 2005b. An examination of recent census and survey data on mortality in South Africa within the context of HIV/AIDS in South Africa in The demography of South Africa edited by T Zuberi A

Sibanda \& E Udjo. New York: M. E. Sharpe Inc Publisher: 90-II9.

Udjo, E.O. 2008. "A re-look at recent statistics on mortality in the context of HIV/AIDS with particular reference to South Africa". Current HIV Research 6:|43-15|.

United Nations Economic Commission for Africa. (1974). Manual on demographic sample surveys in Africa. Addis Ababa: UNECA, p 36.

Van Aardt, C.J. 2007. Population and household projections for South Africa by province and population group, 200I-202I. Bureau of Market Research Report No. 364, Unisa, Pretoria.

Van de Walle, E. 1982. Multilingual demographic dictionary. Liege: International Union for the Scientific Study of Population: I 10.

Walsh, K.L. 2008. The impact of large consumer unit size on water and sanitation services in lower income urban areas in South Africa. Available at http://www.wrc.org.za/Knowledge\%20Hub\%20 Documents/Research\%20Reports/TT-37I-08.pdf Accessed February 202014.

Walsh, K. 20II. Understanding consumer profile. Available at http://view.officeapps.live.com/op/view.aspx?src= http\%3A\%2F\%2Fpdg.co.za\%2Fwpcontent\%2Fuploads\%2F20 I2\%2F04\%2F2-

Consumer-profile-20IIIII07-kw.doc Accessed February 202014. 